\title{
“"The whistle blows, and we are whisked into a tunnel": Railways and the Environment in Illawarra, 1850s-1915'
}

\section{André Brett ${ }^{1}$ \\ $\underline{\text { Introduction }}$}

The interaction of railways with the environment is beginning to emerge as an area of interest within disciplines such as environmental history. Luís Borda-de-Água, Rafael Barrientos, Pedro Beja, and Henrique M. Pereira, in an interdisciplinary, international overview of railway ecology — that is, the role of railways within ecosystems-emphasise there is much work to be done. They explain that information on the effects of railways on landscapes, wildlife, and biodiversity is currently scarce and scattered, and requires engagement from scholars across a range of disciplines. ${ }^{2}$ The concept of railway ecology highlights the distinctiveness of rail transport within environmental history. Railway corridors create and contain environments different from those of other modes of transport, both in their construction and operation. Grades, to take one example, must be gentler than for roads. This necessitates large interventions in the landscape, such as tunnels, deep cuttings, and high embankments, which alter local hydrology and animal habitats. Nicholas Crane's historical geography of Britain describes the 'entirely new linear habitats' of railways as inducing 'topographic shock.'3 Crane's observations also apply to landscapes throughout Britain's seven colonies in Australasia, from semiarid plains to mountain passes.

\footnotetext{
${ }^{1}$ This article is based on my winning essay for the 2020 Wollongong Local History Prize, for which I would like to express my sincerest gratitude to the judging panel and the Friends of the Wollongong City Library (the library holds the original). I am also very grateful to Rachel Harris, Jatinder Mann, and my two anonymous reviewers for their comments, encouragement, and suggestions.

${ }^{2}$ Luís Borda-de-Água, Rafael Barrientos, Pedro Beja, and Henrique M. Pereira, "Introduction," in Railway Ecology, eds. Luís Borda-de-Água, Rafael Barrientos, Pedro Beja, and Henrique M. Pereira (Cham: Springer, 2017), 5.

${ }^{3}$ Nicholas Crane, The Making of the British Landscape: From the Ice Age to the Present (London: Weidenfeld and Nicolson, 2016), 442-46.
} 
Rail transport aided European settlers to cross what Warwick Frost dubs the 'wet frontier' and clear thick forests for intensive farming. ${ }^{4}$ Railways re-made floodplains and influenced attitudes to water, formed an essential component of large-scale wheat cultivation schemes, and enabled primary producers to expand output through access to new markets. ${ }^{5}$ To date, many studies of railways within Australasian environments focus on a specific extractive industry-forestry is represented particularly well in the publications of the Light Railway Research Society of Australia. It is now worth turning to the distinctive local or regional effects of railways beyond a single industry or commodity, so to better understand the links between technology, environment, and place.

The Illawarra region of New South Wales (NSW) presents a valuable case study. These are the lands of the Dharawal people, who never ceded sovereignty. Beginning at the Royal National Park on Sydney's southern fringe, Illawarra extends down to the Shoalhaven River, where it blurs into the South Coast region. It is wedged between the Tasman Sea to the east and the nearly impassable Illawarra Escarpment (or Illawarra Range) to the west, beyond which are the Southern Highlands. In the words of geographer R.W. Young, the Escarpment 'runs like a great unbreached wall for some $120 \mathrm{~km}$.' It dominates the narrow coastal plains below and has influenced the region's human history profoundly. ${ }^{6}$ Wollongong, the main centre, is today the third-largest city in New South Wales behind Sydney and

\footnotetext{
${ }^{4}$ Warwick Frost, "Farmers, Government, and the Environment: The Settlement of Australia's 'Wet Frontier', 1870-1920," Australian Economic History Review 37, no. 1 (1997): 19-38.

${ }^{5}$ See André Brett, "'The Exceptional Circumstances Under Which We Are Working': Railways and Water in Australasia, 1870s to 1914," History Australia 17, no. 3 (2020): 489-509; D.W. Meinig, On the Margins of the Good Earth: The South Australian Wheat Frontier 1869-1884 (Netley: South Australian Government Printer, 1962), chapter 7; Lionel Frost, "The Railway Corridors," in Outside Country: Histories of Inland Australia, eds. Alan Mayne and Stephen Atkinson (Kent Town: Wakefield Press, 2011), 159-176.

${ }^{6}$ R.W. Young, "The Illawarra Escarpment," Wollongong Studies in Geography 2, (1979): 1-4.
} 
Newcastle, and its growth was more recent than either of those hubs, owing much to the economic stimulus of opening a railway down the precipitous range.

The environmental history of the first decades of rail transport exposes how Wollongong and its region industrialised and the ways in which this process affected everything from primary producers to the sounds of daily life. This article focuses on the government's railway line south from the Royal National Park to Bomaderry on the Shoalhaven River opposite Nowra (see Maps 1 and 2), while also acknowledging short private railways and tramways. It takes in the 1850s through to the start of World War I (WWI), a period when rail transport grew from being the adjunct of a few coal mines into an essential common carrier. Much of this article constitutes envirotechnical analysis, which Sara B. Pritchard describes as 'the ways nonhuman nature affords material constraints to technological development and use. ${ }^{7}$ But it goes beyond this to incorporate insights from disciplines as diverse as economic history and sound history to understand how railway technology, people, and place interacted in Illawarra.

After outlining the construction of the South Coast Railway, this article progresses through a series of themes that show the economic, social, and cultural attributes that shaped and were shaped by the railway environment. It begins with the railway as a carrier: the extent to which trains fulfilled their intended role to transport Illawarra's natural resources to Sydney and other markets. It then moves on to the railway as a consumer, putting the local environment to work for its benefit and requiring materials made from resources of distant lands. Water was especially significant, and its two-way relationship with the railway is the subject of a dedicated

\footnotetext{
${ }^{7}$ Sara B. Pritchard, Confluence: The Nature of Technology and the Remaking of the Rhône (Cambridge: Harvard University Press, 2011), 11.
} 
section: the absence or excess of water affected the operation of trains and shaped the experiences of passengers. Railways did more than move traffic and consume resources: they created their own environment and provided new perspectives on 'nature.' A notorious smoke-choked tunnel at Otford was only the most obvious manifestation. The final section describes how trains brought people closer to nature in the Royal National Park, carried them into new-and dangerous-environments in tunnels, and transformed the sonic landscape. Rail travel differed significantly from horseback or sea voyages in capacity and speed, and by WWI it had become enmeshed in Illawarra's environment.

\section{The railway comes to lllawarra}

For most of the nineteenth century, Illawarra had a relatively small population and economy despite its proximity to the colonial capital and entrepôt, Sydney. Europeans entered Dharawal country from the 1790s-first escaped convicts and explorers, then timber-getters, cattle men, and others—but the journey down the Illawarra Escarpment was so difficult as to impede all but the most determined traveller. Local historian Bill McDonald summarises the original road as 'never much of a road in its best days...All descriptions of it are, in their various ways, uncomplimentary.8

Illawarra was obscure enough to Sydneysiders in 1830 that one newspaper published a lengthy introduction of the region and its 'little boat port', Wollongong. The editor of the Sydney Monitor explained that Illawarra could supply large quantities of dairy, wheat, potatoes, and meat if only transport were better. Residents 'have long been anxious' for a road decent enough that they could 'drive a cart to

\footnotetext{
${ }^{8}$ W.G. McDonald, The Oldest Road (Wollongong: Illawarra Historical Society, 1979), 32.
} 
and fro without breaking of necks. ${ }^{\prime 9}$ Seagoing vessels called at Wollongong and other jetties, but these were small and unsheltered, and another paper, the Sydney Gazette, fretted about the state of Illawarra's 'little havens.' Ships that took cedar and other products to Sydney usually arrived under ballast, as the small local population demanded few bulk items. The Gazette wrote that 'we are informed it is the common practice of their crews, on casting anchor, to throw the ballast, consisting of stones, into the water.' If this continued, 'the harbours will in a short time be choked up.'10 Government investment improved these facilities in subsequent decades, especially with the opening in 1868 of Belmore Basin, Wollongong's block-walled harbour. The replacement of sailing ships with steam-powered colliers enhanced reliability, but capacity remained limited, subject to the vagaries of weather and tides.

European settlers knew of Illawarra's mineral deposits from the 1790s, but there was no remunerative market without a larger local population or cheap transport. Dairy, instead, came to dominate the regional economy. Joseph Gordon, a Scottish poet who sojourned in Australia, waxed lyrical about Illawarra produce in 1849:

This fact, e'er since I cross'd the seas,

I rarely fail at meals to utter

That Bathurst stands unmatch'd for cheese,

And Wollongong for yellow butter. ${ }^{11}$

Gordon must have been a treat at dinner parties. He revised the poem lightly for publication in London in 1861, and although he failed to improve its literary qualities,

\footnotetext{
${ }^{9}$ Sydney Monitor, 6 January 1830, 2.

10 Sydney Gazette, 9 September 1830, 2.

${ }^{11}$ Bathurst Advocate, 28 July 1849, 4.
} 
the depiction of Illawarra as a region of bucolic dairy farms still rang true when he died in 1881 at his Dundee home. ${ }^{12}$

There were, however, signs of change. Fitful efforts to raise coal began in the late 1820 s and presaged the opening of the first significant mines in $1857 .{ }^{13}$ The colonial government recognised that these resources could not be exploited fully without investment in rail transport. Wollongong's railways are the subject of a good corpus of short books and other historical literature, generally written for railway enthusiasts. These publications emphasise operational history and engineering matters and provide a solid basis of fact with which to interpret the environmental history of Wollongong's railways. C. C. Singleton and J. L. N. Southern's regional overviews sit alongside focused studies such as that by D. K. Reynolds on railways in West Dapto and O. F. Jacobson on the Moss Vale-Unanderra line. ${ }^{14}$ John Gunn and Robert Lee integrate larger details into a broader state-wide context in their histories of NSW's railways —especially the challenges of construction to Illawarra. ${ }^{15}$ When these works are coupled with the annual reports of the NSW railway commissioners, newspaper accounts, and other sources, it is possible to gain telling insights about how the railway interacted with the Illawarra environment and created its own distinctive spaces.

\footnotetext{
12 Joseph Gordon, Botany Bay, and Other Poems (London: Arthur Hall, Virtue and Co., 1861), 227229.

${ }^{13}$ Arthur Cousins, The Garden of New South Wales: A History of the Illawarra and Shoalhaven Districts 1770-1900, $2^{\text {nd }}$ ed. (Wollongong: Illawarra Historical Society, 1994 [1948]), 161-164.

14 O. F. Jacobson, Illawarra Mountain Railway, New South Wales (Wollongong: Illawarra Historical Society, 1977); D. K. Reynolds, The Railways of West Dapto (Wollongong: BHP-Billiton, 2001); C. C. Singleton, Railway History in Illawarra, New South Wales, $4^{\text {th }}$ ed. (Wollongong: Illawarra Historical Society, 1984 [1964]); J. L. N. Southern, A Railway History of the Illawarra (Melbourne: BHP Papers, 1978).

15 John Gunn, Along Parallel Lines: A History of the Railways of New South Wales, 1850-1986 (Melbourne: Melbourne University Press, 1989); Robert Lee, Colonial Engineer: John Whitton 18191898 and the Building of Australia's Railways (Sydney: UNSW Press, 2000); Robert Lee, The Greatest Public Work: The New South Wales Railways, 1848 to 1889 (Sydney: Hale and Iremonger, 1988).
} 
The first steam railway in Australasia opened from central Melbourne to its port in 1854; the Sydney Railway Company had begun constructing a line between Sydney and Parramatta earlier, but it did not open until 1855, by which point it was in the hands of government commissioners. This company's failure set a pattern in Australasia-local private capital was insufficient to fund construction and operating returns were too small to attract overseas investors. After a handful of false starts and failed companies, all seven of Britain's Australasian colonies developed large public railway networks. By the end of the 1870s, NSW could boast lines that ran hundreds of kilometres from Sydney and Newcastle to Orange, Tamworth, and Wagga Wagga. Illawarra, however, had no public railway-and not for want of trying.

Horse tramways from mines to jetties provided Illawarra's first rail transport. The Osborne-Wallsend Colliery at Mount Keira opened a line in 1859 and over the next few decades other collieries built their own tramways to Belmore Basin and to jetties at Austinmer, Bellambi, Bulli, and Port Kembla. Some of them did not solely use animal power: in 1867 the first locomotive to raise steam in Illawarra ran on the Bulli Coal Company's tramway, and in 1879 Osborne-Wallsend obtained Wollongong's first steam locomotive. ${ }^{16}$ These tramways, small and rudimentary, served the commercial interests of their owners and did not link towns or operate as common carriers.

Agitation for a railway to Sydney began in the early 1870 s, with advocates forming a regional coalition of interested parties to press their case on parliament, but their efforts took a decade to bear fruit. Historian Henry Lee exposes the political and business interests that delayed the railway in A History of Wollongong: Newcastle MPs feared Illawarra would become a rival to the Hunter coalfields, while

\footnotetext{
${ }^{16}$ Singleton, Railway History, 7.
} 
pastoralists hankered after investment in the international wool trade. Even some Wollongong residents were wary-mostly those with financial interests in shipping. ${ }^{17}$

NSW's parliament in March 1881 approved the South Coast Railway from Sydney to Illawarra as part of a large plan of railway expansion. Construction began in October 1882, although controversy about the route down the Escarpment caused delays. These delays were not the result of engineering difficulties, which were considerable, but of Premier Alexander Stuart favouring a more expensive route, one that would improve the value of property he owned. John Whitton, the engineer-inchief, stared down Stuart and the line followed his intended alignment. ${ }^{18}$ It opened in stages: Hurstville in 1884, Sutherland in 1885, Waterfall in 1886, and an isolated section in Illawarra during 1887-Clifton to Wollongong in June, then Wollongong to Bombo (originally called North Kiama) in November. The region celebrated the completion of its link to Sydney on 3 October 1888, and the southernmost section to Bomaderry, on the north bank of the Shoalhaven River opposite Nowra, opened on 2 July 1893. ${ }^{19}$

Trains, of course, did not work alone: the seaborne mineral trade remained important until the 1930s. But the railway's role was large, and as it induced sweeping changes in the Illawarra environment, it also created environments of its own. If Joseph Gordon could have seen the region in 1915, he might barely have recognised it, from the clattering trainloads of coal to the factories pumping smoke

\footnotetext{
${ }^{17}$ Henry Lee, "'Rocked in the Cradle': The Economy, 1828-1907," in A History of Wollongong, eds. Jim Hagan and Andrew Wells (Wollongong: University of Wollongong Press, 1997), 45-46.

${ }^{18}$ Lee, Greatest Public Work, 105.

${ }^{19}$ For a more detailed account of construction, particularly south of Kiama, see Alan Clark and Robyn Florance, Going South: Constructing the Railway Kiama to Bomaderry (Nowra: Shoalhaven Historical Society, 2018). For information on plans to extend the line further to Jervis Bay, see Peter Crabb, Destination Jervis Bay: Railways that Never Were (Huskisson: Lady Denman Heritage Complex, 2013).
} 
into the air and contaminating the water of Lake Illawarra. The new railway environment had its own distinctive qualities-some might have said discomforts.

\section{Railways as a carrier}

Colonial governments throughout Australasia constructed railways to stimulate the productivity of established towns and ports and to grow the settler economy in as-yet lightly occupied hinterlands. The South Coast Railway drew on both motivations: it aimed to support the established dairy industry and to encourage extraction of auriferous resources. Government railways were not intended to accrue profit but to provide cheap transport for people and goods-if revenue exceeded running costs significantly, users expected and usually received reductions in fares and charges. Charles Goodchap, NSW's commissioner of railways from 1878 to 1888 , boasted that the colony's 'judicious system of railway extension' meant that 'large tracts of land, at present comparatively unproductive, will become capable of supporting a thriving population, the resources of the country will be developed, and the general prosperity of the whole community rapidly and materially increased. ${ }^{20}$ This logic underpinned investment in railways with high capital costs or where low initial tonnages meant revenue would not cover operating expenses for some years.

Illawarra's natural wealth, both known and anticipated, made the South Coast Railway a high-profile project. When Goodchap submitted his 1885 annual report to parliament in July 1886, he took the unusual step of describing an event after the end of the year under review - the opening of the section from Sutherland to Waterfall on 9 March 1886. This event of 'considerable importance,' he wrote, 'brings

\footnotetext{
${ }^{20}$ NSW Government Railways Annual Report 1879, 31. The annual and quarterly reports (hereafter NSWGRAR and NSWGRQR) were tabled in parliament and printed in the bound volumes of the NSW parliamentary papers and also issued as individual publications held at the State Library of NSW. Railway statistics here are from the relevant annual report unless otherwise cited.
} 
us nearer to the coal-fields and rich district of Illawarra. ${ }^{21}$ The railway was useful in serving Hurstville and Sutherland, but Illawarra was the prize.

The South Coast Railway affected Illawarra's landscape even before construction began. English and colonial capitalists invested in mining companies once the line was approved, and the industry burgeoned during the 1880s. By the time the railway opened, Illawarra produced almost a fifth of NSW's coal. ${ }^{22}$ Yet the line did not win traffic immediately. It cost almost $£ 2.2$ million to build, over $£ 30,000$ per mile, and operating losses in its early years were large—almost $£ 57,000$ in 1892 and over $£ 38,000$ in 1893 . Only one NSW railway lost more money in the same period. It ran from Armidale to the Queensland border, and in contrast to the Illawarra line it had cost less than $£ 12,000$ per mile to construct and had the benefit of enabling intercolonial travel. ${ }^{23}$ The South Coast Railway, however, was far from a failure. Illawarra no longer depended on coastal colliers or tides and weather to distribute goods. Wollongong residents could visit Sydney and return the same day. Goods were loaded at a local station one evening and sold at a Sydney market the next morning. These attributes gradually secured significant traffic.

Most importantly, Illawarra coal could be exploited in much larger quantities. Henry Lee suggests that Illawarra's coal trade in the twentieth century's first decade 'continued to depend on Wollongong Harbour and the jetties. ${ }^{24}$ Colliers did retain a large role, but rail had broken the industry's reliance on waterborne transport. Table 1 shows the rapid growth in tonnages from modest volumes during 1889/90, the first full financial year that trains ran to Sydney, through to almost 1.35 million tons of coal

\footnotetext{
21 NSWGRAR $1885,7$.

${ }^{22}$ Lee, "Rocked in the Cradle," 45.

${ }^{23}$ NSWGRAR 1893/94, 9. Usage note: two years separated by a slash indicates a financial year ending 30 June, e.g. 1893/94 is the year from 1 July 1893 to 30 June 1894.

${ }^{24}$ Lee, "Rocked in the Cradle," 51.
} 
and other minerals in 1914/15. Even in 1909/10, during which coalminers pursued significant strike action, almost 650,000 tons of coal went by rail.

It is unfortunate that coal production figures for Illawarra mines cannot be compared directly to railway tonnages: coal was reported for the calendar year, while the railways in 1888 switched to reporting for the financial year ending $30 \mathrm{June}^{25}$ Approximations must suffice. Coal output was booming in Illawarra when the South Coast Railway opened but the amount despatched by rail in 1889/90 represented only about a tenth of the total output for either 1889 or 1890 . This changed rapidly. The railway coal tonnages of 1899/1900 and 1914/15 represented about half the coal raised in the calendar years.

\begin{tabular}{|c|c|c|c|c|c|}
\hline \multicolumn{6}{|c||}{ Table 1: outwards freight tonnages on South Coast Railway } \\
(all stations Helensburgh-Bomaderry) \\
\hline $\begin{array}{c}\text { Year ending } \\
30 \text { June }\end{array}$ & Coal & $\begin{array}{c}\text { Other } \\
\text { minerals }\end{array}$ & Goods & Total & $\begin{array}{c}\text { Coal/minerals } \\
\text { as } \% \text { of total }\end{array}$ \\
\hline $1889 / 90$ & 65,894 & - & 50,197 & 116,091 & $56.76 \%$ \\
\hline $1899 / 1900$ & 577,150 & 15,646 & 37,724 & 630,520 & $94.02 \%$ \\
\hline $1909 / 10$ & 642,264 & 46,902 & 52,149 & 741,315 & $92.97 \%$ \\
\hline $1914 / 15$ & $1,093,991$ & 242,347 & 78,153 & $1,414,491$ & $94.47 \%$ \\
\hline \hline
\end{tabular}

${ }^{25}$ Coal output in this paragraph and the next is from T. A. Coghlan, The Wealth and Progress of New South Wales, $10^{\text {th }}$ issue, 1896-97 (Sydney: Government Printer, 1897), 225; H. C. L. Anderson, Official Year Book of New South Wales 1906-7 (Sydney: Government Printer, 1907), 688; J. B. Trivett, Official Year Book of New South Wales 1916 (Sydney: Government Printer, 1917), 288. Together, these volumes provide a full run from 1887 to 1915. 
Trains might have carried an even larger proportion of coal had the line not reached capacity by 1900 . Additional crossing loops, installed in 1901, enabled more trains to use the line and kept freight moving but with 'intolerable delays. ${ }^{26}$ Coastal shipping, therefore, continued to prosper, transporting almost 960,000 tons of coal in $1902 .{ }^{27}$ This became its peak year: coal sent by sea fell to 517,846 tons by 1907 , even though annual production grew from almost $1.6 \mathrm{~m}$ tons to over $1.8 \mathrm{~m}$ in the same period. After 1915, when the first of two double-tracked deviations down the Escarpment opened, rail obtained the dominance in coal transport that was anticipated from the outset.

It is also worth emphasising that rail played a major role in facilitating shipping during the pre-war decades-most coal could not have been exported without the private tramways between mines and jetties. As the government's trains overtook shipping, the mines brought coal to the South Coast Railway rather than continuing to the seaside. The tramways to Wollongong Harbour, once vital, closed in the 1930s, and today joggers and cyclists rather than steam engines puff along the Blue Mile Tramway shared path.

The South Coast Railway enabled industrialisation beyond coal mining. The Smelting Company of Australia, for example, established a large facility at Dapto in the mid-1890s. Its proprietors envisaged transforming Lake Illawarra into a harbour to accommodate intercolonial seaborne trade, but this scheme never transpired. Instead, rail linked the smelter with mineral producers and customers throughout NSW. One visitor in 1899 described the 'tall chimney stacks belching forth clouds of smoke, locomotives passing two [sic] and fro, and numerous men at work.' He

${ }^{26}$ Singleton, Railway History, 21.
${ }^{27}$ Lee, "Rocked in the Cradle," 52. 
reported that as well as despatching wagons of gold, silver, and lead bullion, the smelter received trainloads of limestone from Portland in the Central Tablelands, iron ore from Carcoar in the Central West, and pyrite all the way from Cobar for making sulphuric acid. ${ }^{28}$ The company might not have remade Lake Illawarra to suit its purposes, but it began the process of industrial pollution that peaked in the second half of the twentieth century. Metals contaminated the lake water, especially lead, zinc, and copper; vegetation suffered from lead and sulphur fumes or was felled. ${ }^{29}$ Such pollution was not the direct result of railway operation, but it would not have happened if the railway had not made the associated industries viable.

Another extractive industry that benefitted from the South Coast Railway was quarrying. Kiama residents used local basalt (blue metal) for roadbuilding in the 1860s, and Sydney began using it in 1870 . George Hill opened a quarry at Bombo in 1883 , and within a couple of years it was the biggest in NSW. ${ }^{30}$ The government acquired land to quarry at Bombo in 1889, largely to meet the railway network's demands, described further below. More quarries near the railway line opened in subsequent years-some owned privately, while at Port Kembla the government extracted large blocks for breakwaters and crushed stone for roadbuilding and concrete. Some quarries with jetties, such as at Bombo, despatched much of their output by colliers, while others depended on rail. During 1914/15, for instance, $70 \%$ of the Bombo state quarry's output of 120,000 tons went by collier and the rest by rail, while trains carried all 53,000 tons of stone crushed at Port Kembla. ${ }^{31}$ This

\footnotetext{
${ }^{28}$ Sydney Morning Herald, 8 February 1899, 4.

29 Joseph Davis, Lake Illawarra: An Ongoing History (Wollongong: Lake Illawarra Authority, 2005), 73.

${ }^{30}$ Cousins, Garden of New South Wales, 183-187.

31 J. B. Trivett, Official Year Book of New South Wales 1915 (Sydney: Government Printer, 1917), 205206.
} 
provided the basis for further quarrying between Shellharbour and Kiama after WWI, which relied even more heavily on rail for transport.

What of the Illawarra's celebrated dairy industry and other agricultural pursuits? The railway had been built to serve these too: shipping could not compete with rail for time-sensitive goods. While reliant on seaborne transport, butter often arrived in Sydney rancid when shipped in summer. ${ }^{32}$ The railway opened new markets for farmers. One writer in Sydney's Daily Telegraph described a daily milk train from Kiama in August 1889 that at every station 'picks up enormous numbers of cans of milk, which will serve for enriching to-morrow morning's cup of coffee.'

Alongside these milk cans, he observed casks of butter, cases of eggs, and crates of poultry. ${ }^{33}$ Dairy farmers increasingly specialised in producing milk and forewent production of other items such as cheese and bacon. Trains from Sydney delivered those goods to Wollongong, though a correspondent in the Sydney Mail complained in early 1894 that 'breakfast bacon [from Sydney] at some of the hotels on the coast is as hard as a proverbial brick. ${ }^{34}$

The reporter had choice words for perceived failings of Illawarra farmers as well, but he gave a detailed account of the railway milk trade. Stations between Wollongong and Albion Park handled the largest quantities, usually in ten-gallon cans, the produce of about 5,000 cows-in winter almost all output went to Sydney, while in summer about half did, with local butter factories using the surplus. There were refrigerated facilities at each end for storage, but the wagons were not cooled artificially as the railway journey took 4.5 hours at most, and milk reached consumers 'thoroughly free from sourness.' Trains then returned the cans for re-use.$^{35}$

\footnotetext{
32 Lee, "Rocked in the Cradle," 41.

${ }^{33}$ Daily Telegraph (Sydney), 24 August 1889, 9.

${ }^{34}$ Sydney Mail, 10 February 1894, 267.

35 Ibid.
} 
Fishing was another good example of an industry that flourished when supplied with railway access. Lake Illawarra fishermen sent their entire catch to Sydney by rail, except what they sold for local consumption. Bream, tarwhine, flathead, mullet, and other fish were conveyed in a manner that the local fisheries inspector in 1898 considered 'crude': they were packed tightly into boxes and loaded onto whatever wagon was available. Some boxes went by the guard's van of passenger trains, others were placed in open trucks or closed vans of goods trains, and as a rule they went at night in summer to avoid spoilage. 'Considering the large quantity of fish and the mode of transit,' the inspector concluded, 'the quantity condemned on arrival at the metropolitan markets as unfit for human food is very small. ${ }^{36}$

Dairy farmers and other primary producers in Illawarra did not meet the railway as equals: the railway mattered more to them than their goods mattered to the railway. Tonnages by station were, unfortunately, reported in aggregate-only tons of coal and other minerals were specified separately. ${ }^{37}$ Table 1 shows that coal and minerals surged ahead while other goods tonnages stalled. Goods other than coal comprised almost $45 \%$ of the total traffic on the line in $1889 / 90$, soon sliding to only $5-7 \%$, with the highest proportion in $1909 / 10$ when strikes reduced the coal tonnages. Some context, however, is important. Illawarra butter production passed a million pounds for the first time in 1910 , and even if this all went by rail it would have contributed only 450 tons. Likewise, if trains had carried that year's entire estimated

\footnotetext{
36 Illawarra Mercury, 16 August 1898, 2.

${ }^{37}$ The annual reports specify the bales of wool, bags of wheat, trucks of hay, straw, and chaff, and numbers of livestock, but collapse the tonnages of these consignments into the goods column. For example, Bomaderry station (then called Nowra) received 114 trucks of hay, straw, and chaff in 1914/15 but the tonnage of these 114 trucks is collapsed into the 5,116 tons of inbound goods.
} 
milk yield of 4.1 million gallons, this would have been about 19,000 tons-and milk production was declining, falling by over 600,000 gallons by $1914 / 15 .{ }^{38}$

These goods made a larger financial contribution per ton than minerals did, as perishable commodities attracted premium tariffs while Australian railways barely broke even on coal. Again, official statistics are deficient: for each station, freight revenue is given in total only. It is possible, though, to make a rudimentary comparison between a coal station and a dairy one. Scarborough despatched 153,092 tons of coal in $1914 / 15$ and only 256 tons of other commodities, earning $£ 10,621$ at $£ 0.07$ per ton. Albion Park, one of the main stations for dairy, despatched 9,865 tons of goods (and no minerals) for $£ 2,362, £ 0.24$ per ton. The greater value is clear-but with coal and other minerals forming nearly $95 \%$ of freight tonnages, any other commodity was small beer no matter what tariff it attracted.

\section{Railways using the environment}

Railways put the environment to work. Environmental historian Heather Goodall has used the term 'work' to describe two overlapping understandings: whether an ecosystem or landscape is functioning well (itself a loaded term) or whether it is economically productive.$^{39}$ In the case of the railways, it was very much the latter: construction and operation demanded landscapes be remade and their resources extracted and refined for use. To run trains through Wollongong, railway engineers not only drew on local resources but also placed demands on environments across the world.

\footnotetext{
${ }^{38}$ Henry Lee, "'A Corporate Presence: The Economy, 1908-1945," in A History of Wollongong, eds. Jim Hagan and Andrew Wells (Wollongong: University of Wollongong Press, 1997), 55.

39 Heather Goodall, "Working Rivers", International Review of Environmental History 4, no. 1 (2018): $111-124$.
} 
Items of iron and steel came from England's great grimy industrial centres. Australian attempts to roll rails had, at the time, proven unsatisfactory-BHP did not begin large-scale rail production until April 1915—so NSW ordered vast quantities from its imperial centre. The annual railway reports enumerate imports by manufacturer, and Charles Cammell and Company of Sheffield supplied the rails for NSW's railway extensions in the $1880 s .{ }^{40}$ Sheffield was a hub of rail production, and steelworks such as Cammell's typically sourced iron ore from mines in England and Wales, especially Cumbria. Expanding demand meant that English steelmakers also used ore from continental Europe and North Africa. ${ }^{41}$ In Smethwick, west of Birmingham, the Patent Nut and Bolt Company produced most of the fastenings required to hold the rails together. The South Coast Railway could only be completed because miners extracted iron ore from beneath Britain's surface, steelworkers in the Midlands and Yorkshire forged it into shape, and seamen transported it across the globe to Australia.

Other than rails and fastenings, engineers and contractors sourced materials locally. Wherever possible, they used resources from the area through which the line passed, and if those did not meet their needs they looked elsewhere in NSW. The three million bricks that lined Otford Tunnel, for example, were made with clay excavated from the tunnel itself. ${ }^{42}$ Workmen moved earth and modified its contours to create gentle grades for trains. It was common practice to form embankments with fill from nearby cuttings and tunnels, and each mile of railway required over two

\footnotetext{
40 See returns in the NSWGRARs of permanent way materials imported, e.g. NSWGRAR 1887, appendix 6, 44.

${ }^{41}$ K. Warren, "The Sheffield Rail Trade, 1861-1930: An Episode in the Locational History of the British Steel Industry," Transactions and Papers of the Institute of British Geographers 34, (1964): 131-57; D. C. Goldring and L. M. Juckes, "Iron Ore Supplies to the United Kingdom Iron and Steel Industry," Mining Technology 110, no. 2 (2001): A76.

42 William A. Bayly, Tunnels on Australian Railways (Bulli: Austrail Publications, 1972), 24.
} 
thousand sleepers. The contractors established an adzing facility at Garden Hill (today Hospital Hill) near Wollongong station to finish sleepers for the whole line between Clifton and Macquarie Rivulet. ${ }^{43}$ Neither the annual reports nor newspapers clarify the source of this timber. It was commonplace throughout Australia to cut sleepers from trees nearby, but shipping records also show vessels from Manning River regularly landing sleepers at Wollongong during $1886 .{ }^{44}$ It is possible to estimate the quantity of timber used with a method I have previously outlined for Victoria. ${ }^{45} \mathrm{NSW}$ has a slightly narrower rail gauge, but its sleepers were similar in size and the lower band of my method for Victoria provides a reasonable minimum estimate of the timber that went under the rails. It assumes each sleeper contained 30 super feet of timber, which works out as at least 6.1 million super feet $\left(14,400 \mathrm{~m}^{3}\right)$ for the original alignment of the South Coast Railway all the way from Sydney to Bomaderry, which had double track as far as Hurstville. More timber was used, as this estimate allows only for sleepers in the main line, not yards or sidings.

The ballast of the South Coast Railway comprised Illawarra basalt, and it became a common ballast throughout NSW. The contractors for the section between Clifton and Macquarie Rivulet quarried alongside American Creek near Unanderra. They obtained three crushers to break stone during the middle of 1886 and distributed ballast in two stages. Workmen spread an initial layer on the earthen formation, laid the rails, and packed the line with a second layer to mitigate slackness in the rails and subsistence of the formation. ${ }^{46}$

\footnotetext{
43 Illawarra Mercury, 13 April 1886, 2, and 18 May 1886, 2.

44 Illawarra Mercury, 24 November 1885, 2.

${ }^{45}$ André Brett, "Railways and the Exploitation of Victoria's Forests, 1880s-1920s," Australian Economic History Review 59, no. 2 (2019): 167.

46 Illawarra Mercury, 5 June 1886, 2.
} 
The railway opened at an ideal time, as the plentiful basalt around Kiama provided ballast for a network-wide renewal programme. NSW's parliament appointed an independent commission to operate the railways at a distance from political interference in 1888 , and the inaugural commissioners found that sandstone and gravel ballast on many lines had perished into small shards and dust. They resolved to re-ballast with basalt and other hard rock materials, and to pack it to a $60 \%$ greater depth. The Bombo quarry acquired in 1889 formed a large part of this programme: it was one of NSW's two main railway quarries, the other at Bowral, with smaller quarries opened elsewhere. A decade later, the commissioners reported that they had used almost 1.5 million tons of ballast, principally basalt, and they attributed Bombo and the other quarries with reducing costs by $70 \% .{ }^{47}$ During the first half of the twentieth century, most ballast used within 160 kilometres of Sydney was Bombo basalt. ${ }^{48}$ Illawarra's resources were essential to the safe operation of NSW's busiest railways, and the landscape around Bombo was transformed.

\section{$\underline{\text { Railways and water }}$}

Water is especially significant for steam railways - it is a resource essential for daily operation and an environmental agent whose perceived quality, excess, or absence has major consequences. Locomotives and rollingstock required regular cleaning, especially wagons used for dirtier commodities, and staff and passengers needed drinking water. Most importantly, locomotives heated water to generate steam and create energy. Railway staff in Illawarra were, like their counterparts throughout

\footnotetext{
${ }^{47}$ NSWGRAR 1898/99, appendix: ten years' retrospect, 45.

${ }^{48}$ Singleton, Railway History, 55.
} 
Australia, concerned heavily with the availability of water, focusing on its industrial suitability rather than its potability. ${ }^{49}$

Illawarra is a well-watered region without some of the challenges common to railway lines in semi-arid locations throughout Australia, but the relationship between the South Coast Railway and local waterbodies could be exploitative or fraught. The railway drew large quantities. Some stations sourced water directly from nearby waterbodies, while others used town supplies for a fee. Otford was a significant watering location in the early decades, equipped with columns that could fill two trains at once from a nearby stream. Dapto had a dedicated stop for water at Mullet Creek until about 1907 , when a pipeline brought water to the station precinct. ${ }^{50}$ In Kiama and Nowra, the railway commissioners paid local authorities one shilling per thousand gallons in 1900. This was a fairly standard rate-indeed, it was cheaper than what Victoria's railways paid in a number of locations. ${ }^{51}$ That year, Kiama station gained two tanks that held 8,000 gallons, just over a day's supply, in case the town water was interrupted..$^{52}$ Usage burgeoned: by 1914 , the commissioners purchased 125,000 gallons per week at Kiama. ${ }^{53}$

Illawarra experienced drought less often than many regions of NSW but it did not escape dry periods such as the Federation Drought, which affected most of the continent from 1895-1903. A severe drought occurred in Illawarra during 1895-97, and it recorded a near-constant monthly deficiency of rainfall from 1904 to $1910 .^{54}$ The situation in 1897 was so bad that water trains ran daily to Otford. This was no

\footnotetext{
49 Brett, "Exceptional Circumstances," 495.

50 Singleton, Railway History, 34, 51.

51 Victorian Railways, water returns, VPRS 3253, unit 869, Public Record Office Victoria.

52 Illawarra Mercury, 15 September 1900, 2; South Coast Times, 14 July 1900, 5, and 16 November $1901,7$.

53 Daily Telegraph, 26 February 1914, 9.

54 J.C. Foley, Droughts in Australia: Review of Records from Earliest Years of Settlement to 1955 (Melbourne: Bureau of Meteorology Bulletin no. 43, 1957), 60-63.
} 
isolated example: to name just two others, the same occurred at Helensburgh in 1902 and again at Otford in $1909 .{ }^{55}$ Dry months in the 1910 s exposed a major problem for the railways with buying water-local authorities could suspend service. This happened at Kiama in March 1913 and again in February 1914 when railway usage was draining the town supplies dry. The installation of back-up tanks at the station in 1900 had proven far-sighted and the railway commissioners ordered a pumping plant for use at Minnamurra River so that they had a larger supply under their control. ${ }^{56} \mathrm{After} \mathrm{WWI}$, the number of watering stations declined as larger and more efficient locomotives needed to refill less frequently.

Flooding represented the other extreme. Illawarra's connection with Sydney was only so good as its ability to withstand wet weather, and rainfall kept maintenance staff busy. George Cowdery, engineer for existing lines, found the South Coast Railway a burden from the moment it opened, prone to landslides and subsistence. This was truly an envirotechnical landscape, where non-human nature constrained the use of rail technology. Singleton's Railway History colourfully describes the route down the Escarpment as laid on soil that becomes 'porridge-like in wet weather. ${ }^{57} \mathrm{He}$ highlights challenges in the first eighteen months after the railway opened but does not mention that these were partly foreseen. Difficulties occurred between Waterfall and Clifton because the large embankments had not yet consolidated. This was normal: new railways took months to settle and engineers allowed for this. But the Escarpment's unstable landscape posed extraordinary risks to safety. Cowdery wrote of his staff giving 'the closest attention' to keeping the line safe, with repairs required after every rainfall before trains could resume. ${ }^{58}$

\footnotetext{
55 Illawarra Mercury, 28 June 1902, 2; South Coast Times, 20 February 1909, 11.

${ }^{56}$ Nowra Leader, 7 March 1913, 4; Daily Telegraph, 26 February 1914, 9.

${ }^{57}$ Singleton, Railway History, 16.

${ }^{58}$ NSWGRQR October-December 1888, minute from engineer of existing railways, 5 .
} 
Nobody, however, could have predicted the 'Great Wet' of May 1889, a phenomenal week-long downpour that brought practically the entire NSW network to a halt. Cowdery believed it affected the South Coast Railway worse than any other line, and his staff committed 'great care and unusually heavy expenditure' to minimise delays. ${ }^{59}$ This formal language put matters lightly: miners and other labourers were hired to assist the railway's maintenance gangs and they toiled at repairs in pelting rain and thick flowing mud. Many of these men, hardy and accustomed to onerous work, walked off the job exhausted and chilled to the bone. Multiple attempts to send trains through ended with passengers disembarking and having to trudge through muddy cuttings and along windswept embankments to another train or a horse-drawn coach. ${ }^{60}$ One such attempt resulted in two trains colliding inside Otford Tunnel, fortunately without fatalities.

The Illawarra Mercury narrated the story of a group who took 22 hours to reach Wollongong-or, in the case of one of their number who had been in the tunnel accident, fifty hours. Their misadventure included hair-raising attempts to ford rivers, trying and failing to make their way on foot along part of the railway line through 'squashy matter' and an 'agglutinating mass' of mud, and scrambling around temporarily abandoned ballast wagons with their luggage. The reporter hoped that in time this 'fair admixture of amusing incident' would leave their memories 'spiced and flavoured.' ${ }^{\text {61 }}$ Extended periods of rainfall persisted throughout the colony until July 1890, with repairs continuing for months thereafter. ${ }^{62}$ It was a dramatic illustration

\footnotetext{
59 NSWGRAR 1888/89, 13.

${ }^{60}$ D. Audley, "Railway Operations in the 'Great Wet'-May 1889," Australian Railway Historical Society Bulletin 34, no. 544 (February 1983): 28, 37-38, 42-44.

61 Illawarra Mercury, 1 June 1889, 2.

62 NSWGRAR 1890/91, 4.
} 
that as much as the railway cut a grand swathe through the landscape, it remained at the mercy of the elements.

\section{Experiencing the environment}

People who rode the South Coast Railway or lived near it experienced an environment with new or distinctive qualities. Three aspects stand out-the railway made 'nature' more accessible, tunnels defined the railway environment for many travellers, and trains changed Illawarra's soundscape. The first change was not only foreseen, but actively sought: railway authorities anticipated that the South Coast Railway would bring travellers to sites of natural beauty. Its route passed through the National Park, proclaimed in 1879 and as yet unadorned with the title Royal. A short branch for day-trippers left the main line at Loftus. Commissioner Goodchap anticipated that traffic to 'this pleasure ground for the people' would sustain the portion of the line between Sydney's southern suburbs and the coalfields for years to come. ${ }^{63}$ There was a more prosaic reason for constructing this branch-it served an army camp in the park. But Goodchap was right to expect many visitors. The park proved so popular a destination that part of the branch was duplicated in $1899 .{ }^{64}$ Discounted excursion tickets from Sydney and Illawarra swelled passenger numbers during the 1890s, prompting one newspaper to hail the journey as 'one of the cheapest, as it is one of the most delightful, in Australia.' The writer congratulated railway officials for popularising the park's 'pleasant rambles', 'umbrageous restingplaces', and 'noble views of the broad Pacific.' 65 Frank Farnell, chair of the National

\footnotetext{
${ }^{63}$ NSWGRAR 1885, 7.

${ }^{64}$ Peter Neve, Railways (and Tramways) in the Sutherland Shire, Sutherland Shire Studies pamphlet no. 6 (Sutherland: Sutherland Shire Historical Society, 1975), 4.

${ }^{65}$ Australian Star (Sydney), 25 January 1894, 2.
} 
Park Trust, estimated in 1914 that the railway accrued $£ 12,000$ annually for carrying 250,000 people to the park. ${ }^{66}$

Passengers who rode beyond Waterfall described the South Coast Railway as giving a new impression of nature. Tunnels, deep cuttings, tight curves, and the speed of the train meant that the landscape was not experienced as a slowly evolving vista from horseback or a ship's deck. The original route ran through eight tunnels between Waterfall and Clifton and six more south of Oak Flats. A visitor in 1894 described a pleasant morning journey from Sydney as far as Waterfall, where 'a stranger is surprised to see the gas lit, although the sun is shining brightly.' The reason for the gas lamps being illuminated 'soon becomes plain. The line goes through mountains, and over deep ravines, one tunnel after another in quick succession, so that there is need of light in the carriages. ${ }^{67}$ An earlier writer wrote with awe about 'the funeral procession of tunnels which have forced a right-of-way through grounds vainly thought safe from intrusion.' ${ }^{68}$ The chronicler of a Tramway Association excursion in 1890 described the suddenness of descending the Escarpment and arriving at the ocean: the train 'popped through tunnel after tunnel like hide-and-go-seek' until it reached Otford Tunnel-a long and notorious hole through Mount Bulgo-and when it 'shot out of the tunnel, the view was beautiful past description.'69

This perspective on nature was unlike anything that travellers to Illawarra experienced previously, and reactions varied. Some responses suggest an enthusiasm for the new perspectives that 'modern' travel created, while other accounts reveal anxieties about these industrialised environments. One passenger in

\footnotetext{
66 Daily Telegraph, 19 February 1914, 8.

67 Port Macquarie News, 10 February 1894, 7.

68 Sydney Morning Herald, 1 February 1890, 6.

69 Illawarra Mercury, 30 October 1890, 2.
} 
1889 marvelled, describing the 'transformation effected by the plunge....into a tunnel and the sudden emergence upon the open beach by the side of the laughing sea' as 'one of the great natural sights of the district. ${ }^{.70}$ Rail travel provided aesthetic pleasures for this writer. Others considered it a hurried way to look upon the world. One visitor from the Port Macquarie region in 1894 underscored that this new perspective could be unsettling: 'just as one is beginning to admire the scenery,' the anonymous traveller wrote, 'the whistle blows, and we are whisked into a tunnel, to come out on an entirely different scene. ${ }^{.71}$ Whether enthralled or slightly disconcerted, accounts of travel in the early years of the South Coast Railway uniformly praised the views from the train as it descended the Escarpment. Impressions of the return journey were more negative. No aspect of Illawarra's railway environment occasioned more comment than its tunnels and the effects of steam locomotion within them. The way in which they reframed nature was just one component-the environment inside the tunnels was new, surprising, often uncomfortable, and sometimes terrifying. Two tunnels developed fearsome reputations: the $624 \mathrm{~m}$-long Helensburgh (or Metropolitan ${ }^{72}$ ) Tunnel and the $1.5 \mathrm{~km}$ long Otford Tunnel, the longest in Australia at the time of construction. Railway historian William Bayly condemned the latter as 'by far the most notorious tunnel in Australia,' a singular impediment to fostering leisure traffic. ${ }^{73}$ These narrow tunnels were ventilated poorly, and Otford had further marks against it: a steep 1-in-40 uphill grade for Sydney-bound trains, and southerly breezes that trapped smoke at the northern end. This meant that when a train for Sydney entered the tunnel, working

\footnotetext{
${ }^{70}$ Daily Telegraph, 24 August 1889, 9.

${ }_{71}$ Port Macquarie News, 10 February 1894, 7.

72 Singleton, Railway History, 59, calls this the Metropolitan Tunnel and gives Helensburgh Tunnel as the name of a much shorter tunnel nearby. The pre-WWI sources cited here refer to the longer tunnel as Helensburgh.

${ }^{73}$ Bayly, Tunnels on Australian Railways, 40.
} 
hard to climb the grade, the wind pushed forward the locomotive's smoke and heated the atmosphere ahead. The Illawarra Mercury gave a harrowing account of a picnic special on 22 October 1890:

Even with all the windows shut, the carriages got full of smoke and steam. The engine snorted, and coughed, and puffed.... with the smoke and steam and grit in the carriages, everybody had to sneeze, too, as if they had got into a pepper storm in the dark. There we were, as if we were to be buried alive. Darkness all around us like the grave, and the engine playing the Dead March...Children cried and screamed as well as they could in the smoky darkness; women swooned and fainted, and in every way it looked as if the whole lot of picnicers were going to be stifled and smoked into bacon, to say the least. ${ }^{74}$

The train stalled and had to reverse from the tunnel, with the locomotive taking the carriages through in two segments. This was not uncommon: newspapers from the 1890 s to the 1910 s recount many similar delays.

Passengers suffered in the tunnels, and locomotive crews had even more traumatic experiences. Less than three years after opening Otford Tunnel, the railway commissioners approved a ventilation shaft. ${ }^{75}$ It unfortunately had little to no effect. Enginemen improvised face coverings and crouched as low as possible to breathe cooler-but still oppressively hot-air. ${ }^{76}$ Even this was not always sufficient. Engine driver Neil M'Ginley fainted in Otford Tunnel while working a morning train to Sydney on 9 April 1894 and died that night, his death attributed to apoplexy. ${ }^{77}$ M'Ginley's fate was forgotten quickly, perhaps because the apoplexy diagnosis permitted causation to be attributed elsewhere than the tunnel environment. When several enginemen were scalded in Helensburgh Tunnel in 1906, the railway

\footnotetext{
74 Illawarra Mercury, 30 October 1890, 2.

75 Sydney Morning Herald, 28 May 1891, 5.

76 Singleton, Railway History, 15.

77 Evening News (Sydney), 10 April 1894, 6. Other reports spell his last name as M'Ginlay, M'Gunlay, or M'Quinley.
} 
commissioners claimed that South Coast tunnels presented little risk and had been worked safely for eighteen years. They nonetheless ordered that train loads be reduced and investigated ventilation and deviation schemes. ${ }^{78}$

The matter came to a head in 1908. At the start of October, Mark Morton, a Nowra resident and state MP for Allowrie, averred to 'constant complaints' about the tunnels. In parliament he asked the treasurer, Liberal Reform colleague Thomas Waddell, when relief would be provided. Waddell reported that workmen were installing a ventilation system in Otford Tunnel, and that surveyors had identified a new and gentler route to avoid five tunnels, including Helensburgh. ${ }^{79}$

An unpleasant incident less than two months later underscored the importance of Morton's question. A locomotive crew was overcome by steam and suffered serious injuries after a signal held their goods train in Helensburgh Tunnel on 17 November 1908. George Young, the driver, was 'almost in a state of collapse' and fireman James Darlington fell from the locomotive. The heat was so intense that 'both men were severely burnt about the face, the skin peeling off. ${ }^{\prime 80}$ Morton demanded the situation receive 'immediate attention,' and a week later Robert Hollis, Labor MP for Newtown, pressed on Waddell the urgency of ventilating these 'deathtraps.' Waddell tried to deflect the incident as the result of 'exceptional conditions' but conceded the need for a deviation. ${ }^{81}$ The tunnels had become a reputational liability as well as a safety hazard. The Kiama Independent, reporting on enginemen Young and Darlington, remarked that the tunnels were 'a proved deterrent to the

\footnotetext{
${ }^{78}$ Daily Telegraph, 19 November 1906, 8.

${ }^{79}$ New South Wales Parliamentary Debates (NSWPD), 1908, second session, 1,353.

80 Illawarra Mercury, 17 November 1908, 2.

81 NSWPD, 1908 second session, 2,601 and 2,739. The 'death-traps' quote is not printed here but appears in the transcript in the South Coast Times, 5 December 1908, 24.
} 
South Coast district as a resort for tourists. ${ }^{82}$ Visitors came once, and the ride home put them off another trip. Something had to be done.

The railway commissioners approved ventilation for Otford Tunnel with a system that Marco Saccardo patented in the 1890 s to ventilate smoke-choked tunnels on Italy's Porrettana Railway between Bologna and Pistoia. ${ }^{83} \mathrm{~A}$ fan delivered 300,000 cubic feet of air per minute through a duct into the northern end of tunnel. This created a 15-knot breeze to push smoke, soot, and other impurities out the southern portal, ostensibly purifying the tunnel within three minutes. ${ }^{84}$ It entered service during January 1909 and initial reports were positive. The Daily Telegraph reported that 'engine-drivers and others' now found the tunnel 'quite cool and even pleasant in comparison. ${ }^{85}$ Real estate agents even used it to promote land sales in Stanwell Park now that there was an 'easy, quick, cheap journey' to Sydney. ${ }^{86}$ Saccardo's system did not quite live up to this optimism. The fan failed on multiple occasions and, when strikes in November 1909 interrupted the supply of coke, railway officials shut the fan down temporarily to conserve the coke that powered it for more urgent needs. ${ }^{87}$ Further problems emerged: the fan blew smoke into the locomotive cab rather than sending it over or around the train, and southerlies combined with the forced air to create hot, sooty swirling winds within the tunnel.

In the end, the railway commissioners built two deviations simultaneous with duplicating the line to Wollongong (excepting the Clifton tunnel, which remains a single track today). The Helensburgh Deviation from Waterfall to Otford opened in

\footnotetext{
82 Kiama Independent, 21 November 1908, 2.

${ }^{83}$ Charles Prelini, Tunneling: A Practical Treatise, $6^{\text {th }}$ ed. (New York: D. Van Nostrand Company, 1912 [1901]), 330. Saccardo's first patent in the European Union's Espacenet database is CH4194A, Switzerland patent no.4914, applied 31 August 1891, published 31 March 1892, followed by GB189802026A, United Kingdom patent no.2026, applied 25 January 1898, published 2 April 1898.

${ }^{84}$ Evening News, 8 March 1909, 7. See also NSWGRAR 1908/09, 6.

${ }^{85}$ Daily Telegraph, 26 January 1909, 6.

${ }^{86}$ Sydney Morning Herald, 16 January 1909, 21.

87 Sydney Morning Herald, 19 November 1909, 8.
} 
stages from 26 January 1914 to 30 May 1915; it was longer, descending the Escarpment with a series of sweeping bends, but it was more gently graded and its tunnels commodious. WWI delayed the Stanwell Park Deviation, but when it opened on 10 October 1920, train crews and passengers could celebrate that Otford Tunnel was gone forever. ${ }^{88}$

Locals did not need to catch a train to experience changes in the Illawarra environment, as the railway redefined the region's soundscape. Sound history has recently become a field of research, and this sense is not so ineffable as to evade analysis. Auditory change has played a large role in defining the industrial world. Steven Connor, in a pioneering work of the genre, describes modern noise as endogenous-'modern man is surrounded by man-made noise. ${ }^{89}$ In Australia, Diane Collins identifies the 1850 s goldfields of Victoria as a sonic rupture characterised by gunfire, stones clanging in metal sifters, and water slurping in pans. Other regions experienced similar ruptures when they industrialised. This, she writes, created 'backwards listening, an idealising of the imagined quiet and order of pre-modern pastoral sound-scapes,' and natural Australian environments were invested with an 'apparent noiselessness. ${ }^{.90}$

Celebrated poet Henry Kendall grew up in Illawarra and penned evocative accounts of its pre-industrial soundscape. The ocean broke with 'muffled moans' as 'fragrant wood-winds... with a fitful cadence sung/'mid the ghostly branches belting

\footnotetext{
${ }^{88}$ Singleton, Railway History, 21-26.

${ }^{89}$ Steven Connor, "The Modern Auditory I," in Rewriting the Self: Histories from the Renaissance to the Present, ed. Roy Porter (London: Routledge, 1997), 209.

90 Diane Collins, "A 'Roaring Decade': Listening to the Australian Gold-fields," in Talking and Listening in the Age of Modernity: Essays on the History of Sound, eds. Joy Damousi and Desley Deacon (Canberra: ANU Press, 2007), 9. Elsewhere, Collins argues that the natural sounds of Australia were so unlike those of Europe that explorers interpreted this unfamiliarity as desolation and silence: "Acoustic Journeys: Exploration and the Search for an Aural History of Australia", Australian Historical Studies 37, no. 128 (2006): 1-17.
} 
round the shores of Wollongong. ${ }^{91}$ He repeatedly underscored the ocean's sonic primacy as well as highlighting native birds and European additions such as the barking of farm dogs. Kendall died in 1882, by which point mining had introduced the first tones of an industrial soundscape. Pit whistles signalled the start and finish of shifts, and they were harbingers of greater noise to come.

The steam railway has a distinctive sonic texture, from the rhythmic click-clack of wheels across the joints of rails to the hiss of the locomotive as it departs a station and the deep chugging when straining up a grade. The noise that carries furthest is the whistle, audible for miles by design. 'Keira', the first locomotive in Wollongong, ran on the private line from the Osborne-Wallsend Colliery at Mount Keira. At about 3pm on 20 November 1879, it began 'snorting and whistling' at the head of a train in front of a large crowd of curious onlookers, some of whom scrambled aboard the wagons for a joyride. ${ }^{92}$ An anonymous Old Pioneer reflected on this 'red letter day' as 'a big thing for Wollongong.' It opened a new epoch in the auditory experience of residents. Just like the goldfields residents that Collins studied, Old Pioneer idealised the time before the 'whistle and rumble' of the steam engine as 'the silence of the bush.' The breaking of waves, lowing of cows, and rustle of the wind all collapsed beneath the piercing whistle into an imagined silence. Over the next few years, the novelty wore off and 'Wollongong became quite used to the loco whistles. ${ }^{.93}$ The South Coast Railway represented an increase in railway noise rather than a transformation, and it became part of the rhythm of daily life. At the dawn of the

\footnotetext{
${ }^{91}$ Henry Kendall, "Wollongong," in The Poems of Henry Kendall: With Biographical Note by Bertram Stevens (Sydney: Angus and Robertson, 1920), 33-35.

92 Illawarra Mercury, 21 November 1879, 2.

93 Old Pioneer, Old Pioneer's Reminiscences of Illawarra, comp. Michael Organ and A. P. Doyle (Woonona: Illawarra Historical Publications, 1989), 10-11. Frank Young of the Illawarra Mercury published the Old Pioneer reminiscences from multiple sources-including, later, his own writing —and the author of the initial reminiscences, including the one quoted here, remains obscure.
} 
twentieth century, for example, the whistle of the 8am Sydney train at Albion Park told dairy farmers that it was mealtime. ${ }^{94}$

The regular tooting of locomotives did not impress everyone. In October 1893, the 'whistling and screeching' of a locomotive interrupted David Lindsay Dymock while he gave a speech in front of the Lake Illawarra Hotel in Brownsville. Dymock, a prominent figure in the dairy industry, blurted 'what a nuisance this railway in Illawarra is!' to chuckles from the audience, and a reporter surmised that those assembled did not share the sentiment. ${ }^{95}$ William J. Wiseman, a long-serving alderman and public figure in Wollongong, wrote a sharper complaint to the Illawarra Mercury in May 1890. He bemoaned the 'almost constant nuisance, which is caused by the incessant screeching whistle of the locomotives on the Illawarra railway line.' He worried particularly for 'the poor fellows in the hospital' who were kept awake by 'this screeching old cow of a thing. ${ }^{96}$ That descriptor earned some local popularityan Illawarra traveller in Aotearoa New Zealand reprised it to condemn the whistles of that colony's locomotives. ${ }^{97}$

NSW's railway authorities were unmoved. Locomotive crews used a complex code of whistles to communicate with signalmen and other railway staff. The Sydney Mail attempted to demystify this for readers in 1891: 'the shrill whistle of the locomotive... is full of significance... when the signalman at Redfern Station box A hears a short whistle, followed by two long ones, he knows that the train is proceeding to or from No. 4 platform road and the Illawarra line. ${ }^{98}$ The Illawarra

\footnotetext{
${ }^{94}$ Henry Lee, "The Regional Economy and Its Workforce Communities, 1880-1940," in A History of Work and Community in Wollongong, eds. Jim Hagan and Henry Lee (Sydney: Halstead Press, 2001), 9.

${ }^{95}$ Kiama Independent, 7 October 1893, 4.

96 Illawarra Mercury, 15 May 1890, 2-3.

97 Illawarra Mercury, 3 July 1890, 4.

${ }^{98}$ Sydney Mail, 21 November 1891, 1,142.
} 
soundscape was changed, but for most people those sounds meant progress and a connection with the outside world. If loud whistles could be bothersome, they also suggested the railway was functioning normally and safely.

\section{Conclusion: Environments Remade and Made Anew}

Rail transport was one of the most important contributors to the emergence of Wollongong's industrial environment and, in the process, it created its own environment and provided new perspectives on nature. It was not exclusively responsible for the growth of mining from the 1850s to the 1910s, but its role was immense. The first tramways in Illawarra made it straightforward for mines to deliver coal to jetties; within a decade of the South Coast Railway opening, about half of the region's annual coal production went by train. Established industries used the railway to serve larger markets, with butter and milk able to reach Sydney without spoiling even in summer, but this cargo came to comprise only a small proportion of the tonnages on the line. Trains made new industries viable, such as the smelters supplied with minerals from deep inland, and railway construction and maintenance used large quantities of basalt from quarries.

Basalt is one example of how railways remade the environment and put it to work for the benefit of train travel. Ballast comprising Illawarra basalt stabilised railway tracks throughout NSW; workmen moved vast quantities of soil to open cuttings and form embankments; locomotives drank from waterbodies throughout the region. Some components of the South Coast Railway demanded resources from places far away: iron ore mined in Cumbria became steel rails or nuts and bolts in the foundries of the Midlands and Yorkshire before being placed on a bed of Bombo basalt and Wollongong earth. The tunnels that took the South Coast Railway through 
rugged hillsides were dramatic examples of this envirotechnical landscape, exemplars of the new environment of the steam railway and its hazards. Helensburgh and Otford Tunnels were so notorious that they were bypassed. Tunnels were also one of the more obvious ways in which train travel gave passengers new perspectives on the world: the travelling experience was completely different to that of earlier modes. This could be surprising or unsettling, and so was the railway's auditory contribution. Illawarra's soundscapes were once defined by natural or more-than-human elements and the regular tooting of steam locomotives was a particularly obvious manifestation of the new industrial soundscape. Not everyone appreciated it, but the locomotive whistle became so normal that the time beforehand seemed silent by comparison.

Rail transport ushered in a change from the comparatively light settlement of dairy farmers and timber-getters to a denser population that worked in coalmining and related industries. Trains were reliable and prompt, and a large maintenance staff ensured they remained so even when rain undermined the track or drought demanded that water be delivered from elsewhere. Water, more than any other resource, reminded railway authorities that they could alter but not control natureas much as they adapted the environment to railway purposes, they had to adapt to environmental effects. 'Nature' could also encourage ridership, as seen in the large patronage to the National Park and the gushing reviews of vistas from the South Coast Railway. In 1830, Illawarra had been so obscure that Sydney newspaper editors spelt Wollongong multiple ways, sometimes within the same paragraph. Seven decades later, the railway had not only connected Illawarra with the capital, but it was also now a 'daily occurrence' to travel to 'Bulli with its surrounding 
magnificent scenery, which forms one of the great sights of the colony. ${ }^{99}$ Between the 1850 s and the outbreak of WWI, rail transport had become essential. The railway used and responded to the environment; it created new environments and new perspectives on the environment-in all that the railway did, its effects were large and enduring. Today, whether catching an electric train, walking the Blue Mile to North Beach, or viewing the basalt columns at Bombo Headland's former quarry, the legacy of rail transport in Illawarra is indelible.

${ }^{99}$ Sydney Mail, 28 February 1901, 477. 


\section{Map 1: South Coast Railway}

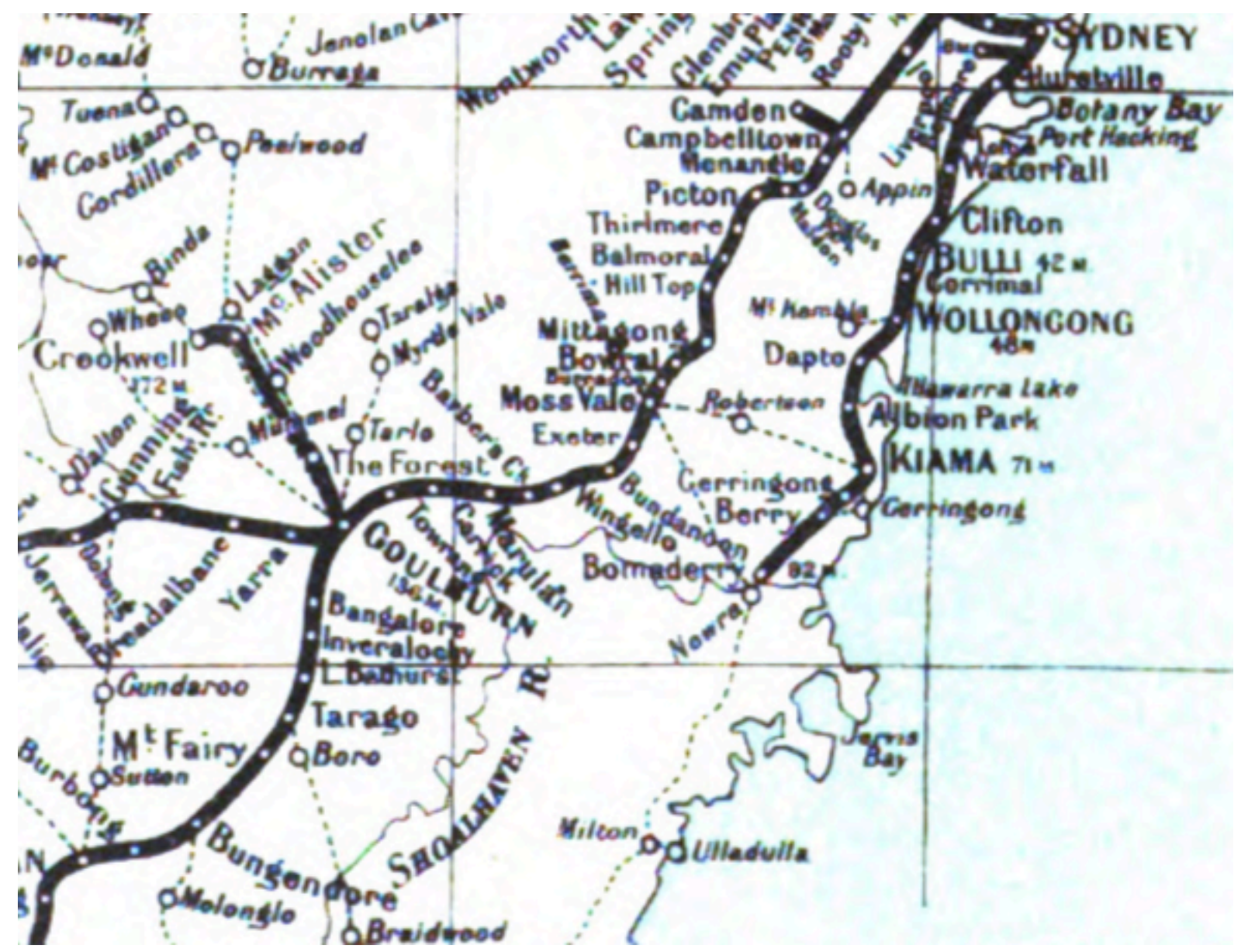

Source: NSWGRAR 1908

Caption: An excerpt from a network map, depicting the South Coast Railway from Sydney to Bomaderry on the Shoalhaven River. Bold lines are open railways; thin dashed lines are coach routes. 


\section{Map 2}

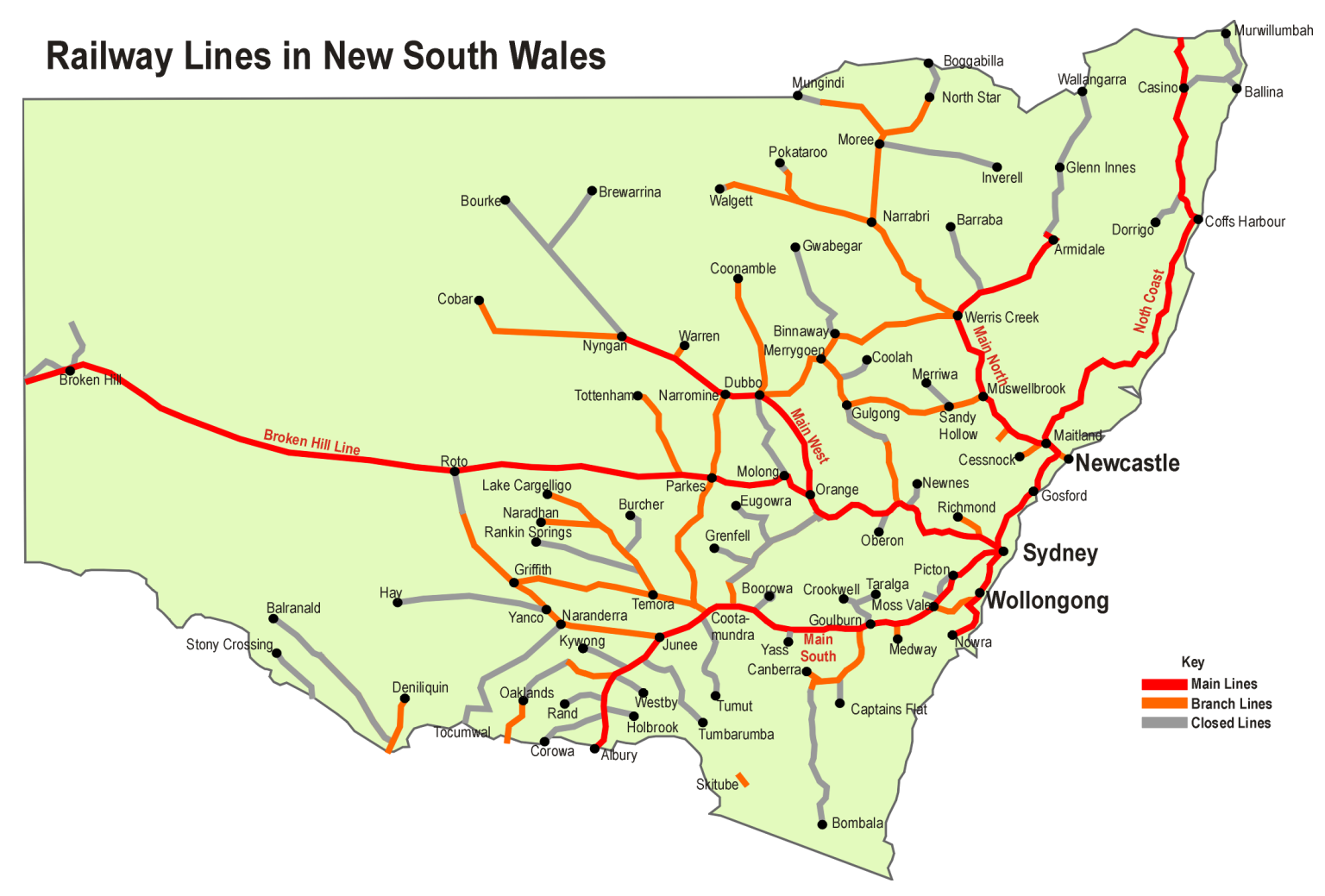

Source: "https://en.wikipedia.org/w/index.php?title=File:NSWRailMap.png" by Quaidy at English Wikipedia, licensed under https://creativecommons.org/licenses/by-

\section{$\underline{\mathrm{sa} / 3.0 / \mathrm{hk} /}$}

Caption: An overview of the NSW railway network circa 2017. Bomaderry station is often known as Nowra, but the railway was never extended across the Shoalhaven River into the town. 
Bibliography:

Official and archival

Anderson, H. C. L. Official Year Book of New South Wales 1906-7. Sydney: Government Printer, 1907.

Coghlan, T. A. The Wealth and Progress of New South Wales. $10^{\text {th }}$ issue, 1896-97. Sydney: Government Printer, 1897.

European Union. Patents CH4194A and GB189802026A. Espacenet database: https://worldwide.espacenet.com/

New South Wales Parliamentary Debates (Hansard). 1908 second session. Available online: https://www.parliament.nsw.gov.au/hansard/pages/home.aspx

New South Wales Government Railways. Annual and quarterly reports, 18751915. State Library of New South Wales.

Trivett, J.B. Official Year Book of New South Wales 1915. Sydney: Government Printer, 1917

—. Official Year Book of New South Wales 1916. Sydney: Government Printer, 1917.

Victorian Railways. Water returns, VPRS 3253, unit 869. Public Record Office Victoria.

Newspapers

Australian Star (Sydney)

Bathurst Advocate

Daily Telegraph (Sydney)

Evening News (Sydney)

Illawarra Mercury 
Kiama Independent

Nowra Leader

Port Macquarie News

South Coast Times

Sydney Gazette

Sydney Mail

Sydney Monitor

Sydney Morning Herald

Books

Bayly, William A. Tunnels on Australian Railways. Bulli: Austrail Publications, 1972.

Clark, Alan, and Robyn Florance. Going South: Constructing the Railway Kiama to Bomaderry. Nowra: Shoalhaven Historical Society, 2018.

Cousins, Arthur. The Garden of New South Wales: A History of the Illawarra and Shoalhaven Districts 1770-1900, $2^{\text {nd }}$ ed. Wollongong: Illawarra Historical Society, 1994 (1948).

Crabb, Peter. Destination Jervis Bay: Railways that Never Were. Huskisson: Lady Denman Heritage Complex, 2013.

Crane, Nicholas. The Making of the British Landscape: From the Ice Age to the Present. London: Weidenfeld and Nicolson, 2016.

Davis, Joseph. Lake Illawarra: An Ongoing History. Wollongong: Lake Illawarra Authority, 2005.

Foley, J. C. Droughts in Australia: Review of Records from Earliest Years of Settlement to 1955. Melbourne: Bureau of Meteorology Bulletin no. 43, 1957. 
Gordon, Joseph. Botany Bay, and Other Poems. London: Arthur Hall, Virtue and Co., 1861.

Gunn, John. Along Parallel Lines: A History of the Railways of New South Wales, 1850-1986. Melbourne: Melbourne University Press, 1989.

Jacobson, O. F. Illawarra Mountain Railway, New South Wales. Wollongong: Illawarra Historical Society, 1977.

Kendall, Henry. The Poems of Henry Kendall: With Biographical Note by Bertram Stevens. Sydney: Angus and Robertson, 1920.

Lee, Robert. Colonial Engineer: John Whitton 1819-1898 and the Building of Australia's Railways. Sydney: UNSW Press, 2000.

—. The Greatest Public Work: The New South Wales Railways-1848 to 1889. Sydney: Hale and Iremonger, 1988.

McDonald, W. G. The Oldest Road. Wollongong: Illawarra Historical Society, 1979.

Meinig, D. W. On the Margins of the Good Earth: The South Australian Wheat Frontier 1869-1884. Netley: South Australian Government Printer, 1962.

Neve, Peter. Railways (and Tramways) in the Sutherland Shire. Sutherland Shire Studies pamphlet no. 6. Sutherland: Sutherland Shire Historical Society, 1975. Old Pioneer. Old Pioneer's Reminiscences of Illawarra, comp. Michael Organ and A. P. Doyle. Woonona: Illawarra Historical Publications, 1989.

Prelini, Charles. Tunneling: A Practical Treatise, $6^{\text {th }}$ ed. New York: D. Van Nostrand Company, 1912 (1901).

Pritchard, Sara B. Confluence: The Nature of Technology and the Remaking of the Rhône. Cambridge: Harvard University Press, 2011.

Reynolds, D. K. The Railways of West Dapto. Wollongong: BHP-Billiton, 2001. 
Singleton, C. C. Railway History in Illawarra, New South Wales, $4^{\text {th }}$ ed. Wollongong: Illawarra Historical Society, 1984 (1964).

Southern, J. L. N. A Railway History of the Illawarra. Melbourne: BHP Papers, 1978.

Scholarly book chapters and journal articles

Audley, D. "Railway Operations in the 'Great Wet'-May 1889". Australian Railway Historical Society Bulletin 34, no. 544 (February 1983): 25-48.

Borda-de-Água, Luis, Rafael Barrientos, Pedro Beja, and Henrique M. Pereira, “Introduction.” In Railway Ecology, edited by Luis Borda-de-Água, Rafael Barrientos, Pedro Beja, and Henrique M. Pereira, 3-9. Cham: Springer, 2017. Brett, André. “'The Exceptional Circumstances Under Which We Are Working': Railways and Water in Australasia, 1870s to 1914." History Australia 17, no. 3 (2020): 489-509. https://doi.org/10.1080/14490854.2020.1796496

—. "Railways and the Exploitation of Victoria's Forests, 1880s-1920s." Australian Economic History Review 59, no. 2 (2019): 159-180. https://doi.org/10.1111/aehr.12158

Collins, Diane. "Acoustic Journeys: Exploration and the Search for an Aural History of Australia." Australian Historical Studies 37, no. 128 (2006): 1-17. https://doi.org/10.1080/10314610608601216

_. "A 'Roaring Decade': Listening to the Australian Gold-fields." In Talking and Listening in the Age of Modernity: Essays on the History of Sound, edited by Joy Damousi and Desley Deacon, 7-18. Canberra: ANU Press, 2007. 
Connor, Steven. "The Modern Auditory I." In Rewriting the Self: Histories from the Renaissance to the Present, edited by Roy Porter, 203-223. London: Routledge, 1997.

Frost, Lionel. "The Railway Corridors". In Outside Country: Histories of Inland Australia, edited by Alan Mayne and Stephen Atkinson, 159-176. Kent Town: Wakefield Press, 2011.

Frost, Warwick. "Farmers, Government, and the Environment: The Settlement of Australia's 'Wet Frontier', 1870-1920.” Australian Economic History Review 37, no. 1 (1997): 19-38.

Goldring, D. C., and L. M. Juckes. "Iron Ore Supplies to the United Kingdom Iron and Steel Industry." Mining Technology 110, no. 2 (2001): A75-A85.

Goodall, Heather. "Working Rivers." International Review of Environmental History 4, no. 1 (2018): 111-124. https://doi.org/10.22459/IREH.04.01.2018.08

Lee, Henry. “A Corporate Presence: The Economy, 1908-1945." In A History of Wollongong, edited by Jim Hagan and Andrew Wells, 53-70. Wollongong: University of Wollongong Press, 1997.

—_. "The Regional Economy and Its Workforce Communities, 18801940." In A History of Work and Community in Wollongong, edited by Jim Hagan and Henry Lee, 9-24. Sydney: Halstead Press, 2001.

—. "'Rocked in the Cradle': The Economy, 1828-1907." In A History of Wollongong, edited by Jim Hagan and Andrew Wells, 35-52. Wollongong: University of Wollongong Press, 1997.

Warren, K. "The Sheffield Rail Trade, 1861-1930: An Episode in the Locational History of the British Steel Industry." Transactions and Papers of the Institute of British Geographers 34, (1964): 131-157. 
Young, R. W. "The Illawarra Escarpment." Wollongong Studies in Geography 2, (1979): 1-4. 